\title{
MUTU KINERJA PENGAWAS SEKOLAH MENENGAH
}

\author{
Oleh: \\ Yohamir Syamsu \\ Universitas Pendidikan Indonesia \\ (email : yohamir234@gmail.com)
}

\begin{abstract}
ABSTRAK
Tujuan penelitian ini adalah untuk mendeskripsikan rekrutmen, kompetensi, motivasi, dan kepuasan kerja pengawas serta pengaruhnya terhadap kinerja pegawas sekolah baik secara persial maupun simultan. Penelitian ini menggunakan metoda survei dengan pendekatan kuantitatif. Pada sekolah menengah Priangan Timur adapaun yang menjadi subjek dalam penelitian ini adalah pengawas sekolah menengah di Priangan Timur. Hasil penelitian menunjukkan bahwa rekrutmen pengawas sekolah tinggi, kompetensi pengawas sekolah pada kategori sedang, motivasi dipersepsikan tinggi, dan kepuasan kerja pengawas sekolah menengah dipersepsikan tinggi. Sedangkan gambaran kinerja pengawas dipersepsikan tinggi. Secara parsial, proses rekrutmen pengawas memberikan pengaruh signifikan terhadap kinerja pengawas. demikian juga variable kompetensi, motivasi, dan kepuasan kerja memberikan pengaruh signifikan terhadap kinerja pengawas. Hasil penelitian menunjukkan pula bahwa secara simultan rekrutmen, kompetensi, motivasi, dan kepuasan kerja memberikan pengaruh signifikan terhadap kinerja pengawas. Rekomendasi dalam penelitian ini agar keberadaan pengawas tidak hanya dijadikan sebagai pelengkap dalam sebuah sistem pengelolaan pendidikan bagi pemerintah daerah. Hasil kerja pengawas dalam bentuk rekomendasi, hendaknya dijadikan sebagai salah satu landasan pengelolaan lembaga dalam melakukan perbaikan atau peningkatan mutu pendidikan.
\end{abstract}

Kata Kunci: Kepuasan Kerja, Motivasi Kerja, Mutu Kinerja, Rekrutmen Pengawas Sekolah.

\section{ABSTRACT}

The purpose of this research was to describe the recruitment, competence, motivation, and job satisfaction of supervisors and their influence on the performance of school officials both in a persial or simultaneous manner. This research uses survey method with quantitative approach. At East Priangan Middle School the subject of this research is the secondary school supervisor in East Priangan. The results showed that recruitment of high school supervisors, the competence of school supervisors in the medium category, high perceptions of motivation, and high school supervisor's job satisfaction perceived high. While the perceived performance of the supervisor is high. Partially, the supervisory recruitment process gives a significant influence on the performance of the supervisor. as well as variable competence, motivation, and job satisfaction have a significant influence on the performance of supervisors. The result of research also shows that simultaneously recruitment, competence, motivation, and job satisfaction give significant influence to the performance of supervisor. The recommendation in this research is that the presence of supervisors is not only used as a complement in an education management system for local government. The work of supervisors in the form of recommendations, should serve as one of the foundations of institutional management in improving or improving the quality of education.

Keywords: Job Satisfaction, Performance Quality, School Supervisor Recruitment, Work Motivation.

\section{PENDAHULUAN}

Pengawas sekolah merupakan komponen dalam sistem pendidikan yang harus turut bertanggung jawab terhadap peningkatan mutu pendidikan, karena keberhasilan penyelenggaraan pendidikkan yang berkualitas sangat terkait erat dengan keberhasilan peningkatan kompetensi dan profesionalisme pendidik dan tenaga kependidikan tanpa menafsirkan faktor-faktor lainnya seperti sarana prasarana dan pembiayaan. Pengawas sekolah merupakan suatu subsistem penting dari keseluruhan sistem pendidikan nasional yang memiliki peranan kuat dalam proses peningkatan mutu pendidikan. Pengawas sekolahpun merupakan salah satu tenaga kependidikan yang posisinya memegang peran yang signifikan dan strategis dalam meningkatkan profesionalisme guru dan mutu pendidikan di sekolah.

Disisi lain kondisi pengawas yang ada sekarang memiliki kompetensi yang rendah. Ini didasarkan pada laporan hasil uji kompetensi pengawas yang dilakukan oleh direktorat pendidik dan tenaga kependidikan tahun 2009, bahwa ratarata penguasaan kompetensi pengawas secara nasional hanya $39,55(56,50 \%)$ dan untuk wilayah 
Priangan timur 39,74. Hasil uji kompetensi pengawas yang dilakukan di seluruh kabupaten/kota di Jawa Barat yang dilaksanakan oleh P4TK IPA tahun 2011 diperoleh hasil dengan kategori kurang (pretes $=42,29$ dan postes $=64,81$ ). Sementara itu penilaian kinerja belum pernah dilakukan terhadap pengawas yang ada, oleh sebab itulah penulis merasa perlu melakukan penelitian tentang kinerja pengawas sekolah menengah.

Berdasarkan beberapa hasil penelitian, dijelaskan bahwa pengawas sendiri, mempunyai peran besar dalam mencarikan jawaban atas perbagai permasalahan yang ada dalam sebuah satuan pendidikan (Nurhadi,2014) dan peran pengawas besar sekali dalam rangka meningkatkan mutu pendidikan (Fauziah,2015; Maisyarah dkk ,2017). Selanjutnya, penelitian yang dilakukan oleh Sasmito (2015) menjelaskan bahwa seorang pengawas sekolah memberikan komtribusi dalam aspek evaluasi pendidikan yang berupa bentuk

\section{Kinerja Pengawas Sekolah Menengah}

Kinerja merupakan terjemahan dari performance yang berarti prestasi kerja, pelaksanaan kerja, pencapaian kerja, unjuk kerja atau penampilan kerja". Kinerja merupakan suatu bentuk hasil kerja atau hasil usaha berupa tampilan fisik, maupun gagasan. Mangkunegara (2005) mendefinisikan kinerja sebagai hasil kerja secara kualitas dan kuantitas yang dicapai oleh seseorang pegawai dalam melaksanakan tugasnya sesuai dengan tanggung jawab yang diberikan kepadanya. Untuk itu kinerja pengawas adalah kemampuan untuk melaksanakan pekerjaan atau tugas yang menjadi tanggung jawabnya. Kinerja merujuk kepada tingkat keberhasilan dalam melaksanakan tugas serta kemampuan untuk mencapai tujuan yang telah ditetapkan. Kinerja dinyatakan baik dan sukses jika tujuan yang diinginkan dapat tercapai dengan baik.

\section{Rekrutmen Pengawas Sekolah}

Rekrutmen diartikan sebagai serangkaian aktivitas yang digunakan oleh sebuah organisasi untuk menarik para pelamar kerja yang memiliki kemampuan dan sikap yang dibutuhkan untuk membantu organisasi dalam mencapai tujuantujuannya. Dalam Human Resource Management, Mondy, R.W \& Noe R.M. (2005:119) menyebutkan bahwa rekrutmen adalah: "The process of attracting individuals on a timely basis, in sufficient numbers, and with appropriate qualification, and encouraging them to apply for jobs with an organization". Proses rekrutmen dimulai dengan upaya menemukan calon karyawan yang memiliki kemampuan dan sikap yang aktifitas atau partisipasi aktif dalam menilai pelaksanaan penerapan dari standar pendidik dan tenaga kependidikan, standar sarana dan prasarana, standar pengelolaan, standar pembiayaan, standar isi, standar proses, standar kompetensi lulusan, dan standar penilaian pendidikan. Oleh karena itu pengawas sekolah harus profesional, berkomitmen, dan berdedikasi dalam pelaksanaan perannya sebagai seorang pengawas.

Seorang pengawas sekolah dalam hal ini adalah seorang supervisor, merupakan salah satu komponen utama dalam sistem pendidikan dimana tanpa perannya maka sistem pendidikan tidak akan berjalan efektif (Fritz dan Miller,2003)

Berdasarkan dari latar belakang, dirumuskan pokok masalah penelitian: Seberapa besar pengaruh rekrutmen, kompetensi, motivasi, dan kepuasan kerja terhadap kinerja pengawas sekolah menengah di wilayah Priangan Timur?

dibutuhkan oleh organisasi dan mencocokkannya dengan tugas-tugas yang harus dijalankan. Menurut Ivancevich (2007:611), salah satu factor yang mempengaruhi tanggapan calon karyawan atau pelamar terhadap langkah rekrutmen yang dilakukan adalah sikap terhadap tugas-tugas dan organisasi, yang didasarkan atas pengalaman social dan pengalaman kerja yang mereka miliki. Selain itu, persepsi mereka atas tugas-tugas juga akan dipengaruhi oleh iklim organisasi.

\section{Kompetensi Pengawas Sekolah}

Dalam pengertian kompetensi pengawas sekolah yang dikemukakan diatas tersirat adanya tiga utama kompetensi. Ketiga ciri itu adalah ; (a) adanya substansi atau materi yang harus dikuasai oleh pengawas sekolah terkait dengan pelaksanaan tugas pokoknya, (b) adanya performance atau tampilan perilaku nyata dari pengawas sekolah dalam melaksanakan tugas pokoknya sebagai pencerminan materi yang telah dikuasainya serta, (c) adanya hasil dari performance perilaku nyata pengawas sekolah dalam bentuk hasil-hasil pengawasan yang tampak dari kinerja sekolah yang dibinanya. Dari pendapat-pendapat tentang kompetensi tersebut diatas, jelaslah bahwa seorang pengawas sekolah perlu memiliki kompetensi professional dalam melakukan pekerjaannya. Kompetensi itu secara umum meliputi: pengetahuan, keterampilan, dan kepribadian yang diwujudkan dalam kebiasaan berfikir dan bertindak dalam melaksanakan tugas kepengawasannya.

\section{Motivasi Pengawas}


Dalam konteks pekerjaan, motivasi merupakan salah satu faktor penting dalam mendorong seorang karyawan untuk bekerja. Motivasi adalah kesediaan individu untuk mengeluarkan upaya yang tinggi ntuk mencapai tujuan organisasi (Stephen P.Robbins, 2001:21). Wexley dan Yukl (dalam As'ad, 2001:57) memberikan batasan mengenai motivasi sebagai the process by which behavior is energized and directed. Pengertian seperti dikemukakan oleh Wexley \& Yukl (1997:98) adalah pemberian atau penimbulan motif atau dapat pula diartikan sebagai hal atau keadaan menjadi motif. Jadi, motivasi adalah sesuatu yang menimbulkan semangat atau dorongan kerja. Motivasi adalah pemberian daya penggerak yang menciptakan kegairahan kerja seseorang, agar mereka mau bekerja sama, bekerja efektif dan terintegrasi dengan segala daya upayanya untuk mencapai kepuasan.

\section{Kepuasan Kerja Pengawas}

Taylor (dalam Houtte, 2006:132) mendefinisikan kepuasan kerja sebagai perasaan seseorang terhadap pekerjaannya. Menurut Blum \& Naylor (dalam Rao, 2003:78), kepuasan kerja merupakan hasil dari sikap seseorang terhadap halhal yang berhubungan dengan pekerjaan dan faktor-faktornya. Kepuasan kerja merupakan reaksi afektif terhadap situasi pekerjaan seseorang, ini dapat dijelaskan sebagai keseluruhan dari perasaan seseorang mengenai pekerjaannya dalam aspek yang spesifik pada suatu pekerjaan. Defenisi lain dikemukakan oleh Osborn dalam Muhaimin (2004:67) bahwa, kepuasan kerja adalah derajat positif atau negatif perasaan seseorang mengenai segi tugas-tugas pekerjaannya, tatanan kerja serta hubungan antar sesamaan pekerja. Kepuasan kerja untuk pengawas adalah perasaan pengawas yang menyenangkan atau tidak menyenangkan mengenai pekerjaannya dan harapan terhadap imbalan yang diberikan.

\section{METODE PENELITIAN}

Penelitian ini menggunakan metoda survei dengan pendekatan kuantitatif. Pendekatan kuantitatif merupakan pendekatanyang digunakan dalam penelitian dengan cara mengukur indikatorindikator variabel penelitian sehingga diperoleh gambaran pengaruh diantara variabel-variabel tersebut. Jenis penelitian ini menfokuskan pada pengungkapan hubungan kausal antar variabel, yaitu suatu penelitian yang diarahkan untuk menyelidiki hubungan sebab berdasarkan pengamatan terhadap akibat yang terjadi.

Penelitian ini dilakukan di sekolah menengah Priangan Timur adapaun yang menjadi subjek dalam penelitian ini adalah pengawas sekolah menengah di Priangan Timur.

Teknik analisis data dalam penelitian ini menggunakan analisis statistik, diantaranya adalah Analisis Deskriptif Variabel Penelitian

Analisis deskriptif dalam penelitian bertujuan untuk melihat kecenderungan distribusi frekuensi variabel serta menentukan tingkat ketercapaian responden pada masing-masing variabel yang diteliti. Untuk melihat gambaran umum setiap variabel dapat diperoleh dari skor rata-rata dengan menggunakan teknik Weighted Mean Scored (WMS) menggunakan rumus berikut:

$$
\begin{aligned}
& \overline{\mathrm{X}}=\frac{\mathrm{x}}{n} \\
& \text { Keterangan : } \\
& \overline{\mathrm{X}}=\text { Skor rata-rata yang dicari } \\
& \mathrm{x}=\text { Jumlah skor gabungan (hasil kali } \\
& \text { frekuensi dengan bobot nilai untuk } \\
& \text { setiap alternatif jawaban) } \\
& \mathrm{n}=\text { Jumlah responden }
\end{aligned}
$$

Hasil WMS kemudian diinterpretasikan (diberi bobot) untuk tiap dimensi yang berhubungan dengan pembentukan mutu sekolah.

Pengujian Hipotesis Penelitian

Untuk mengetahui kesimpulan dari penelitian, dilakukanlah uji hipotesis. Teknik yang digunakan dalam melakukan pengujian hipotesis adalah uji korelasi sederhana, uji korelasi determinasi dan analisis regresi.

\section{HASIL PENELITIAN}

Penafsiran atas koefisien korelasi antar variabel merujuk pada pendapat Natawidjaja (dalam Riduwan, 2005:191) sebagai berikut: 0,00 - 0,20 korelasi kecil, hubungan hampir dapat diabaikan; 0,21 - 0,40 korelasi rendah, hubungan jelas tetapi kecil; $0,41-0,60$ korelasi sedang, hubungan memadai; $0,61-0,80$ korelasi tinggi, hubungan besar; dan 0,81-1,00 korelasi sangat 
tinggi, hubungan sangat erat. Berikut ini disajikan hasil-hasil pengujian hipotesis yang dimaksud.

1. Ada pengaruh positif dan signifikan secara parsial dari rekrutmen terhadap mutu kinerja pengawas sekolah menengah di wilayah Priangan Timur. Adapun korelasinya sebesar 0,777 dengan pengaruh sebesar $60 \%$.

2. Ada pengaruh positif dan signifikan secara parsial dari rekrutmen terhadap kompetensi pengawas sekolah menengah di wilayah Priangan Timur. Adapun korelasinya sebesar 0,684 dengan pengaruh sebesar $47 \%$.

3. Ada pengaruh positif dan signifikan secara parsial dari rekrutmen terhadap motivasi pengawas sekolah menengah di wilayah Priangan Timur. Adapun korelasinya sebesar 0,678 dengan pengaruh sebesar $46 \%$.

4. Ada pengaruh positif dan signifikan secara parsial dari rekrutmen terhadap kepuasan kerja pengawas sekolah menengah di wilayah Priangan Timur. Adapun korelasinya sebesar 0,834 dengan pengaruh sebesar $69 \%$.

5. Ada pengaruh positif dan signifikan secara parsial dari kompetensi terhadap mutu kinerja pengawas sekolah menengah di wilayah Priangan Timur. Adapun korelasinya sebesar 0,671 dengan pengaruh sebesar $45 \%$.

6. Ada pengaruh positif dan signifikan secara parsial dari kompetensi terhadap motivasi pengawas sekolah menengah di wilayah Priangan Timur. Adapun korelasinya sebesar 0,580 dengan pengaruh sebesar $34 \%$.

7. Ada pengaruh positif dan signifikan secara parsial dari kompetensi terhadap kepuasan kerja pengawas sekolah menengah di wilayah Priangan Timur. Adapun korelasinya sebesar 0,601 dengan pengaruh sebesar $36 \%$.

8. Ada pengaruh positif dan signifikan secara parsial dari motivasi terhadap mutu kinerja pengawas sekolah menengah di wilayah Priangan Timur. Adapun korelasinya sebesar 0,788 dengan pengaruh sebesar $62 \%$.

9. Ada pengaruh positif dan signifikan secara parsial dari kepuasan kerja terhadap mutu kinerja pengawas sekolah menengah di wilayah Priangan Timur. Adapun korelasinya sebesar 0,818 dengan pengaruh sebesar $66 \%$.

10. Ada pengaruh positif dan signifikan secara simultan (bersama-sama) dari proses rekrutmen, kompetensi, motivasi berprestasi dan kepuasan kerja terhadap mutu kinerja pengawas sekolah menengah di wilayah Priangan Timur. Adapun korelasinya sebesar 0,758 dengan pengaruh sebesar $57 \%$. Hasil perhitungan pengaruh antar variable tersebut digambarkan sebagai berikut :

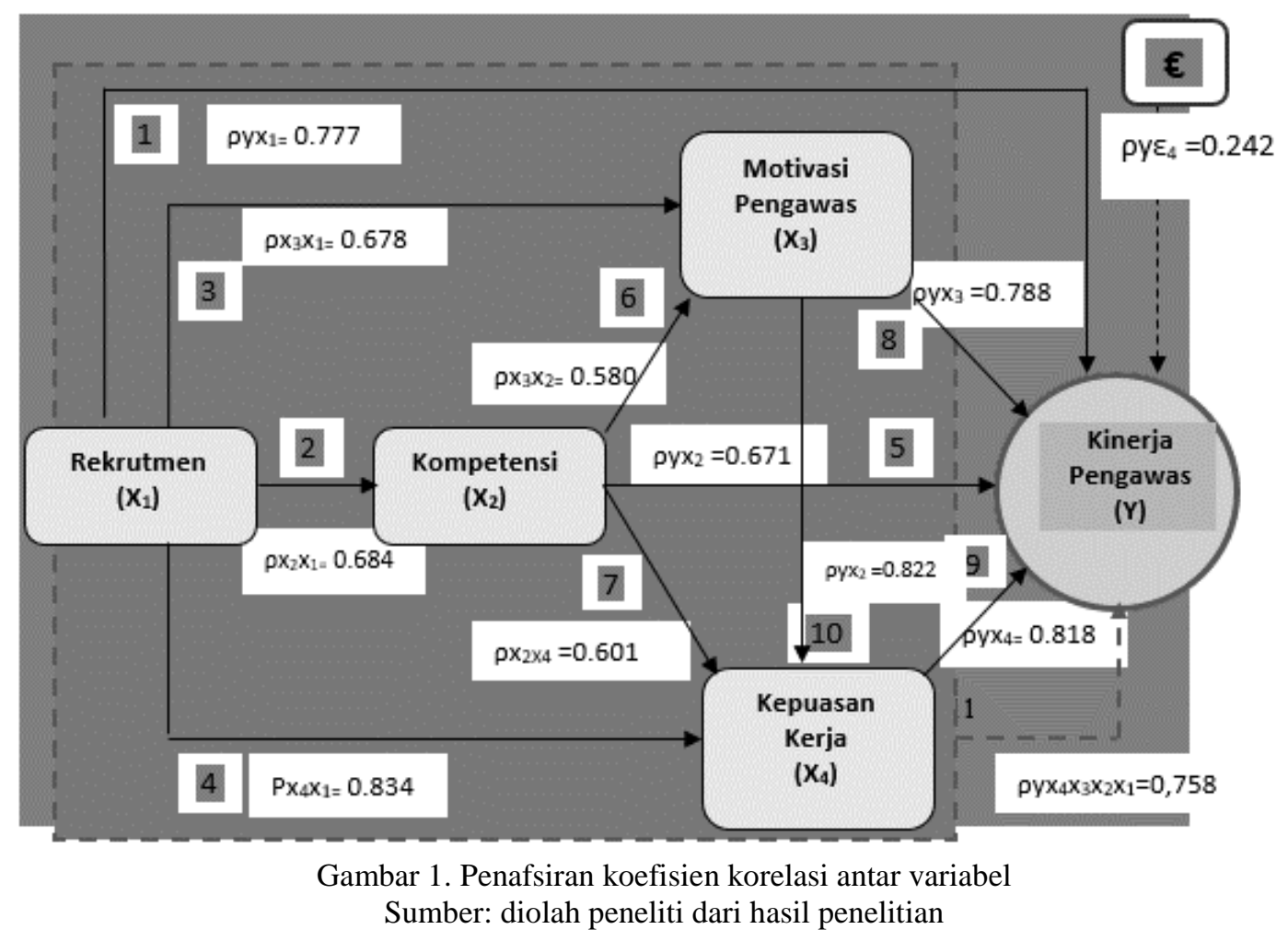


Merujuk pada hasil penelitian di atas dapat diidentifikasi bahwa pengaruh rekrutmen terhadap mutu kinerja pengawas sekolah menengah dinilai sedang $60 \%$. hal ini menunjukan bahwa sistem rekrutmen pengawas sekolah menengah turut berperan terhadap mutu kinerja pengawas sekolah menengah. Sistem rekrutmen adalah bagian dari fungsi administrasi dalam pengelolaan lembaga pendidikan. Seleksi merupakan sebuah proses bagi lembaga pendidikan yaitu dinas pendidikan untuk menempatkan pengawas kedalam sistem yang memiliki tujuan. Oleh karena itu sistem rekrutmen direncanakan dalam sistem yang terintegrasi pada sistem pendidikan. Rekrutmen pengawas sekolah menengah dilaksanakan dengan mengacu pada prosedur dan standar yang telah ditetapkan yang dihubungkan dengan pencapaian visi dan misi pendidikan dalam jangka panjang. Rekrutmen pengawas sekolah menengah merupakan upaya yang dilakukan secara sistematis terencana sebagai bagian dari proses mengintegrasikan atau memadukan usaha individu dan memanfaatkan sumber daya material secara tepat untuk pengembangan efektivitas kualitas manusia. Diharapkan mutu kinerja pengawas sekolah menengah tersebut dapat mendorong ketercapaian tujuan dari pendidikan.

Pengaruh Kompetensi terhadap mutu kinerja pengawas sekolah menengah dinilai sedang, $45 \%$. Administrasi pengelolaan sumber daya manusia dalam lembaga pendidikan merupakan rancangan dan pendekatan secara formal dan sistemik dalam lembaga pendidikan guna menjamin bahwa kompetensi pengawas sekolah menengah dilakukan secara efektif dan efisien guna mencapai tujuan pendidikan. Salah satu kompetensi pengawas yang menjadi sorotan dan dinilai lemah adalah kompetensi dalam Penelitian dan Pengembangan serta menggunakan hasil-hasilnya untuk kepentingan peningkatan mutu pendidikan. Rendahnya budaya meneliti merupakan fenomena yang umum terjadi dalam pendidikan. Ketidakmampuan mengembangkan diri melalui penelitian dan pengembangan mempengaruhi efektivitas kerja sebagai seorang pengawas. Budaya meneliti kurang dimiliki oleh pengawas sekolah menengah, padahal melalui penelitian pengawas sekolah menengah memeperoleh fenomena-fenomena terbaru dalam dunia pendidikan.
Pengaruh motivasi terhadap mutu kinerja pengawas sekolah menengah dinilai tinggi $62 \%$. Motivasi adalah dorongan seseorang berperilaku, dalam kaitannya dengan motivasi pengawas dalam pekerjaan, motivasi turut menentukan mutu kinerja pengawas sekolah menengah. Dalam konsep dasar mengenai kinerja, motivasi, kompetensi dan kesempatan merupakan variabel yang menentukan hasil kerja, faktor-faktor yang mempengaruhi mutu kinerja pengawas sekolah menengah diantaranya adalah motivasi. Tanpa adanya motivasi dan kompetensi serta kesempatan maka sulit mewujudkan kinerja secara maksimal. Motivasi merupakan kondisi jiwa yang mendorong seseorang untuk mencapai kinerja secara optimal.

Pengaruh Kepuasan kerja terhadap mutu kinerja pengawas tinggi yaitu $66 \%$. Kepuasan merupakan aspek emosional yang terdiri dari sikap terhadap pekerjaan, persepsi serta interaksi dalam pekerjaan dengan faktor motivasi internal maupun eksternal. Dalam pekerjaannya sebagai seorang pengawas, faktor yang mendorong kepuasan sangat penting seperti perasaan atas prestasi yang diraih (achievement), kepuasan terhadap pekerjaan itu sendiri, merasa dihargai baik dalam pekerjaannya maupun lingkungannya serta memperoleh kemajuan dalam bekerja sebagai pengawas dan kemungkinan pengembangan karir (the possibility of growth). Faktor internal tersebut perlu dipelihara dan dijaga agar para pengawas tetap merasa puas. Rasa puas tersebut akan mempengaruhi pekerjaannya. Jika lebih puas maka mutu kinerja meningkat. Sumber-sumber yang dapat menciptakan ketidakpuasan berasal dari eksternal pengawas atau disebut dissatisfier (sumber ketidakpuasan) meliputi kompensasi, keamanan dan persepsi pengawas terhadap kepemimpinan kepala organisasi, keselamatan kerja, kondisi kerja, status, prosedur lembaga, mutu dari supervisi teknis dari hubungan interpersonal di antara teman, sejawat, dengan atasan, dan dengan bawahan.

\section{MODEL HIPOTETIK PENGEMBANGAN MUTU SMA}

Model adalah representasi suatu fenomena, baik nyata ataupun abstrak, dengan menonjolkan unsur-unsur terpenting fenomena tersebut. Model jelas bukan fenomena itu sendiri. 
Model hanya sebagai alat untuk menjelaskan fenomena. Suatu model merepresentasikan secara abstrak ciri-ciri penting dan menghilangkan rincian komunikasi yang tidak perlu dalam "dunia nyata". model adalah analogi yang mengabstraksikan dan memilih bagian dari keseluruhan, unsur, sifat atau komponen yang penting dari fenomena yang dijadikan model. Model dapat dikatakan sebagai gambaran informal untuk menjelaskan atau menerapkan teori. Dengan kata lain, model adalah teori yang lebih disederhanakan. Atau seperti dikatakan Werner J.Severin dan James W. Tankard, Jr. Model membantu merumuskan suatu teori dan menyarankan hubungan. Untuk penelitian ini model yang ditawarkan sebagai berikut:

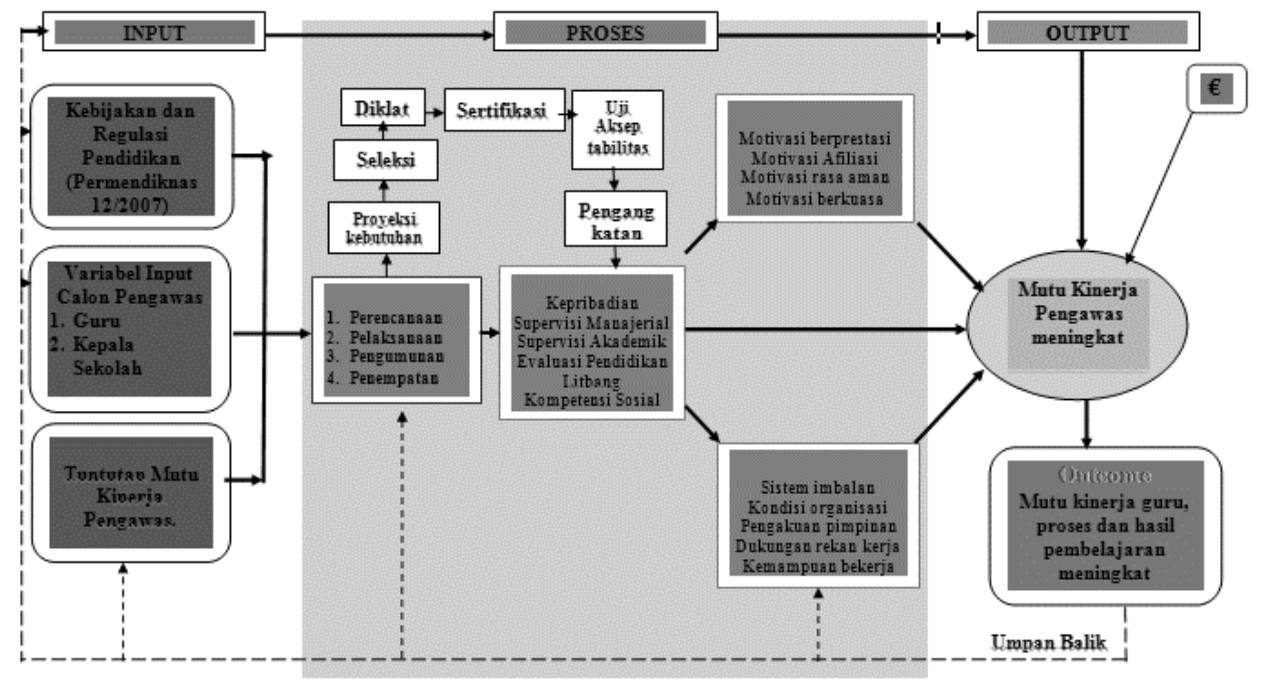

Gambar 2 Struktur Model Hipotetik Strategi Pengembangan Kinerja Pengawas Sumber: dioleh oleh peneliti berdasarkan hasil penelitian

\section{Visualisasi Model}

Struktur model strategi ini adalah sebagai berikut:

a. Komponen konteks adalah lingkungan dan regulasi yang mengharuskan adanya pengawas sekolah. Substansi komponen konteks ini terdiri dari guru dan kepala sekolah, tuntutan mutu pendidikan dan kaitanyya dengan kriteria serta persyaratan pengawas.

b. Input adalah sesuatu yang dimasukkan ke dalam suatu sistem untuk diproses sehingga menghasilkan suatu produk yaitu pengawas yang berkualitas. Input guru dan kepala sekolah merupakan dasar rekrutmen pengawas yang berkualitas.

c. Proses merupakan serangkaian kegiatan yang terencana dan sistematis untuk menghasilkan output dengan cara mentransformasi input. Dalam analisis pengembangan kinerja pengawas, proses ini identik dengan upaya pengembangan potensi dan kompetensi pengawas melalui proses pengembangan keprofesionalan secara berkelanjutan, penciptaan budaya berprestasi dan lingkungan kerja yang kondusif untuk kepuasan kerja pengawas.

d. Output adalah bentuk baru dari input setelah mengalami proses transformasi. Output dari proses tersebut meningkatnya kinerja pengawas.

e. Feedback adalah informasi balikan dari output kepada input dan proses, untuk mengetahui kualitas perubahan input, dan mengendalikan proses, sehingga berangkat dari informasi tersebut dapat dilakukan penyesuaianpenyesuaian agar kualitas output di masa datang menjadi lebih baik.

Indikator Keberhasilan Implementasi Model

Keberhasilan implementasi model strategi pengembangan kinerja pengawas sekolah akan memberikan andil yang cukup besar untuk mendongkrak mutu pendidikan secara umum terutama di sekolah. Indikator keberhasilan implementasi model ini ditunjukan secara rinci sebagaimana berikut:

1. Lahirnya kebijakan pendidikan tentang ketentuan pola rekrutmen pengawas sekolah yang dapat memberi kesempatan sebesarbesarnya bagi calon pengawas untuk mengisi jabatan pengawas sebagai jenjang karir yang terhormat 
2. Meningkatnya kompetensi pengawas melalui berbagai upaya pendidikan dan pelatihan, pengembangan keprofesian, penelitian dan pengembangan, serta penilaian kinerja pengawas.

3. Meningkatnya prestasi pengawas dalam menjalankan tugas pokok dan fungsinya secara optimal, yang ditandai dengan meningkatnya kualitas pembelajaran di sekolah binaan.

4. Meningkatknya kepuasan kerja pengawas sebagai dampak dari lingkungan organisasi yang kondusif, sistem penghargaan yang layak, dukungan pimpinan lembaga terhadap kinerja pengawas, serta dukungan sesama rekan kerja pengawas yang kompak.

5. Terbentuk tim kerja khusus dalam mengawal setiap program kegiatan sekolah melalui berbagai tahapan dan pendampingan, sehingga setiap pelaksanaan program mengacu kepada rencana strategik pengembangan mutu sekolah.

6. Kinerja guru meningkat dengan ditandai oleh semakin disiplinnya guru dan tenaga kependidikan lainnya dalam melaksanakan tugas dan fungsinya

\section{SIMPULAN DAN REKOMENDASI}

Berdasarkan temuan-temuan yang diperoleh dari hasil pengolahan dan analisis data maka penulis dapat mengambil kesimpulan sebagai berikut:

1. Proses rekrutmen, kompetensi, motivasi, kepuasan kerja, dan mutu kinerja pengawas sekolah menengah di Priangan Timur secara umum memiliki klasifikasi tinggi. Hal ini menunjukkan bahwa proses rekrutmen, kompetensi, motivasi, dan kepuasan kerja pengawas dipandang sudah baik dan efektif serta kinerja pengawas sekolah menengah pun dipandang sudah cukup baik.

2. Rekrutmen memiliki pengaruh dengan klasifikasi sedang terhadap kinerja pengawas sekolah menengah di wilayah Priangan Timur, demikian juga rekrutmen dengan kompetensi, rekrutmen dengan motivasi, dan rekrutmen dengan kepuasan kerja memiliki pengaruh dengan klasifikasi sedang. Adapun korelasi antara rekrutmen dengan mutu kinerja pengawas sekolah menengah tinggi. Demikian juga halnya dengan korelasi antara rekrutmen dengan kompetensi, rekrutmen dengan motivasi, dan rekrutmen dengan kepuasan kerja pengawas tinggi. Korelasi tertinggi terdapat pada rekrutmen dengan kepuasan kerja pengawas.

3. Kompetensi memiliki pengaruh dengan klasifikasi sedang terhadap kinerja pengawas sekolah menengah di wilayah Priangan Timur, demikian juga kompetensi dengan motivasi, kompetensi dengan kepuasan kerja, memiliki pengaruh dengan klasifikasi sedang. Pengaruh terkecil terdapat pada hubungan antara kompetensi dengan kepuasan kerja. Adapun korelasi antara kompetensi dengan mutu kinerja pengawas sekolah menengah tinggi. Demikian juga halnya dengan korelasi antara kompetensi dengan motivasi, dan kompetensi dengan kepuasan kerja tinggi.

4. Motivasi memiliki pengaruh dengan klasifikasi tinggi terhadap mutu kinerja pengawas sekolah menengah di wilayah Priangan Timur, demikian juga pengaruh motivasi dengan kepuasan kerja pengawas sekolah menengah memiliki pengaruh dengan klasifikasi tinggi. Adapun korelasi antara motivasi dengan mutu kinerja pengawas sekolah menengah juga tinggi. Demikian halnya dengan korelasi antara motivasi dengan kepuasan kerja tinggi, korelasi tertinggi terdapat pada hubungan motivasi dengan kepuasan kerja pengawas sekolah menengah.

5. Kepuasan kerja memiliki pengaruh dengan klasifikasi tinggi terhadap mutu kinerja pengawas sekolah menengah di wilayah Priangan Timur. Adapun korelasi antara kepuasan kerja dengan mutu kinerja pengawas sekolah menengah sedang.

6. Secara bersama-sama (simultan) Rekrutmen, kompetensi, motivasi dan kepuasan kerja terbukti memberikan pengaruh dengan klasifikasi sedang terhadap mutu kinerja pengawas sekolah menengah di wilayah Priangan Timur. Adapun korelasinya berklasifikasi tinggi.

\section{Rekomendasi}

Berdasarkan kesimpulan yang telah dikemukakan di atas, maka penulis memberikan beberapa rekomendasi berkenaan dengan upaya peningkatan mutu kinerja pengawas sekolah, diantaranya:

1. Dengan memperhatikan bahwa pengaruh rekrutmen terhadap mutu kinerja pengawas sekolah diklasifikasikan sedang, ini 
menyiratkan perlunya mendorong berbagai pihak untuk melakukan upaya pembenahan dan penyempurnaan proses rekrutmen pengawas sehingga menghasilkan pengawas yang professional yang pada akhirnya mampu meningkan kinerja pengawas secara sempurna. Upaya-upaya yang dimaksud diantaranya:

a. Melakukan proses rekrutmen pengawas sesuai dengan regulasi yang ditentukan dan dipersyaratkan sebagaimana tuntutan peraturan mendiknas RI nomor 12 tahun 2007.

b. Perlu dilaksanakannya Need Asessement Test (NAT) untuk mengetahui kebutuhan pengawas, baik kebutuhan dari segi jumlah, kebutuhan mata pelajaran yang diampu atau rumpun mata pelajaran.

c. Untuk mendapatkan pengawas sekolah yang berkinerja baik harus diawali dengan sistem rekrutmen yang baik dengan memperhatikan variabel inputnya yaitu guru dan kepala sekolah yang berprestasi dan memenuhi kriteria yang dipersyaratkan oleh permendiknas nomor 12tahun 2007.

d. Rekrutmen pengawas sekolah harus dilakukan dengan perencanaan yang baik, transparan, dan akuntabilitasnya perlu dijaga sehingga mampu menarik minat calon pengawas yang potensial.

2. Dengan memperhatikan pengaruh kompetensi terhadap mutu kinerja pengawas sekolah menengah diklasifikasikan sedang, dan pengaruh kompetensi terhadap variabel lainnya yang juga diklasifikasikan sedang, ini menyiratkan bahwa kompetensi pengawas belumlah maksimal. Perlu upaya terencana untuk meningkatkan kompetensi pengawas diantaranya:

a. Meningkatkan kualifikasi pengawas sekolah melalui program belajar baik program strata dua (S2), maupun program doctor (S3).

b. Melaksankan kegiatan peningkatan kompetensi pengawas melalui Diklat penguatan kompetensi, seminar, workshop, lokakarya, studi banding dan kegiatan lainnya yang relevan. Jangan sampai terjadi lagi guru atau kepala sekolah sudah ditatar, sementara pengawas yang akan membina guru dan atau kepala sekolah tidak mengetahui apa-apa, sehingga pengawas tidak dapat melakukan tugas pembinaannya terhadap guru dan atau kepala sekolah dengan baik.

c. Dilakukan pengembangan keprofesian berkelanjutan (PKB) seperti pengembangan diri, publikasi ilmiah, dan karya inovatif pengawas. Hal ini berkaitan erat dengan kompetensi pengawas dalam hal pengembangan dan penelitian dimana pengawas sekolah harus membimbing guru dan atau kepala sekolah dalam PKB guru dan atau kepala sekolah.

d. Meningkatkan kemampuan supervisi manajerial dan supervisi akdemik, sehingga kemampuan melaksanakan pembinaan baik kepada guru dan atau kepala sekolah berjalan dengan baik sebagaimana mestinya.

e. Meningkatkan kompetensi kepribadian pengawas sekolah menengah sehingga mampu melakukan pembinaan dengan hati, melakukan revolusi mental terhadap guru dan atau kepala sekolah.

f. Meningkatkan kompetensi sosial pengawas sekolah menengah, sehingga pengawas mampu berkiprah dimasyarakat baik melalui organisasi formal dan non formal kependidikan atau organisasi sosial kemasyrakatan.

3. Dengan memperhatikan pengaruh kepuasan kerja pengawas terhadap mutu kinerja pengawas sekolah menengah diklasifikasikan sedang, ini menyiratkan bahwa kepuasan kerja pengawas belumlah maksimal. Oleh karena itu perlu perbaikan-perbaikan diantaranya:

a. Memberikan pemahaman kepada pengawas bahwa pekerjaan yang diembannya adalah pekerjaan yang baik dan mulia yaitu sebagai penjaminan mutu pendidikan. Faktor yang mendorong kepuasan sangatlah penting seperti perasaan atas prestasi yang diraih, atau kemungkinan pengembangan karier. Faktor internal ini perlu terus dipelihara, dan dijaga agar para pengawas merasa puas, dan perasan puas inilah yang akan mampu meningkatkan mutu kinerjanya.

b. Mengurangi sumber-sumber eksternal yang menciptakan ketidakpuasan pengawas (dissatisfier), diantaranya kompensasi, dan lainnya. Jabatan pengawas merupakan suatu jabatan professional, tetapi jabatan itu tidak mendapatkan tunjangan profesi kepengawasan, justru pengawas mendapatkan tunjangan profesi guru, hal ini perlu difikirkan untuk meningkatkan harkat, martabat dan kepuasan pengawas.

c. Memberikan anggaran operasional yang cukup dan rutin untuk menunjang pelaksanaan pengawas. Selama anggaran operasional tidak diberikan kepada pengawas, bahkan mengandalkan transport dari sekolah, maka selama itu pula kewibawaan pengawas akan hilang, yang 
akhirnya mereka akan menjadi pengawas yang lemah kewibawaannya.

d. Memberikan pendelegasian kewenangan agar pengawas menjadi pengawas yang powerful. Pengawas diberi kewenangan untuk melakukan penilaian kinerja guru, melakukan verifikasi atas guru yang berhak dan layak untuk mendapat tunjangan sertifikasi, serta kewenangan menjadi assessor dalam rangka akreditasi sekolah dan kewenangan lainnya.

e. Memastikan instansi yang betul-betul layak untuk menjadi induk organisasinya. Apabila Dinas Pendidikan sudah tidak mampu melakukan pembinaan, maka ada baiknya kepengawasan berada dibawah lembaga penjaminan mutu pendidikan (LPMP) yang memiliki kesamaan tupoksi yaitu penjaminan mutu pendidikan.

Dengan memperhatikan pengaruh motivasi terhadap mutu kinerja pengawas sekolah menengah diklasifikasikan tinggi, dan pengaruh motivasi terhadap variabel lainnya yang juga diklasifikasikan tinggi, ini menyiratkan bahwa motivasi pengawas merupakan kondisi jiwa yang mendorong seorang pengawas untuk mencapai mutu kinerjanya secara optimal.

\section{DAFTAR PUSTAKA}

As'ad. (2001) Seri Ilmu Sumber Daya Manusia Psikologi Industri. Yogyakarta : Liberty

Fauziah. (2015). Peran Serta Pengawas Sekolah dalam Meningkatkan Kualitas Pendidikan, Menyongsong Masyarakat Ekonomi Asean di Kota Lhokseumawe, Jurnal Pendidikan Ilmu-Ilmu Sosial 7 (2), 145-154.

Fritz, Carrie dan Miller, Greg. (2003). Supervisory Options for Instructional Leaders in Education. Journal of Leadership Education, 2(2), 13-27.

Houtte, Mieke Van. (2006). Tracking and Teacher Satisfaction: Role of Study Culture and Trust. The Journal of Educational Research, $99 \quad$ (4) 247-256. [doi.org/10.3200/JOER.99.4.247-256

Ivancevich, John M. \& Matteson, Michael T., (2007). Organizational Behavior and Managemen. New York: Mc Millan.

Maisyarah S dan Nasir Usman Niswanto (2017). Evektifitas Pelaksanaan Tugas Pengawas dalam Meningkatkan Mutu Pendidikan pada Sekolah Dasar Lingkungan UPTD Suku I Disdikpora Kota Banda Aceh. Prosiding Seminar Nasional Pascasarjana (SNP) Unsyiah 2017, April 12, 2017, Banda Aceh, Indonesia. Diakses melalui http://www.jurnal.unsyiah.ac.id/SNPUnsyiah/article/download/6941/5684

Mangkunegara, Anwar Prabu. 2005. Sumber Daya Manusia Perusahaan. Remaja Rosdakarya: Bandung
Mondy,R.W.,\& Noe III, R.M. 2005. Human Resource Management. (9th Ed.). Massachusetts: Prentice-Hall.

Muhaimin, 2004. Hubungan Antara Kepuasan Kerja Dengan Disiplin Kerja Karyawan Operator Shawing Computer Bagian Produksi Pada PT. Promarindo Asia Infrastruktur TBK Di Bandung. Jurnal Psyche Vol. 1 No: 1.

Nurhadi, Akhmad. 2014. Pengawas Sekolah: Sebuah Pembacaan Peran Dalam Nalar Otonomi Pendidikan, Jurnal Pelopor Pendidikan, 5 (1), 39-48.

Rao, Bhaskara., Sridar, D. (2003). Job Satisfaction of School Teacher. New Delhi : Tarun Offset Printer.

Riduwan. (2005). Belajar Mudah Penelitian untuk Guru, Karyawan dan Peneliti Pemula. Bandung: Alfabeta

Robbins, Stephen P. (2001). Organizational Behavior, New Jersey: Upper Saddle River: Prentice Hall. Inc.

Sasmito, Muhammad Asdar. (2015). Kontribusi Pengawas Sekolah Terhadap Pemenuhan Standar Nasional Pendidikan, Journal of EST, 1(2), 30-45.

Wexley \& Yukl, G.A, 1997. Perilaku Organisasi dan Psikologi Personalia. Jakarta: Rineka Cipta. 
